\title{
The brain activity map: imaging the activity of entire neural circuits
}

Rafael Yuste

From Twenty Second Annual Computational Neuroscience Meeting: CNS*2013

Paris, France. 13-18 July 2013

The function of neural circuits is an emergent property that arises from the coordinated activity of large numbers of neurons. To capture this, we propose launching a large-scale, international public effort, the Brain Activity Map Project, aimed at imaging the full record of neural activity across complete neural circuits. This technological challenge could prove to be an invaluable step toward understanding fundamental and pathological brain processes.

Published: 8 July 2013

Submit your next manuscript to BioMed Central and take full advantage of:

- Convenient online submission

- Thorough peer review

- No space constraints or color figure charges

- Immediate publication on acceptance

- Inclusion in PubMed, CAS, Scopus and Google Scholar

- Research which is freely available for redistribution 